\title{
In vitro Response of Bougainvillea Explants and their Antioxidant Enzymatic Activities Treated with Naphthyl Acetic Acid-Based Synthetic Plant Growth Promoters
}

\author{
Ali Ahmad Sabir', Firdaus-e-Bareen ${ }^{2 *}$, Muhammad Zia-ur-Rehman ${ }^{3}$, \\ Sajid Rashid Ahmad ${ }^{1}$, Muhammad Shafiq ${ }^{1}$ \\ ${ }^{1}$ College of Earth and Environmental Sciences, University of the Punjab, Lahore, Pakistan \\ ${ }^{2}$ Department of Botany, University of the Punjab, Lahore, Pakistan \\ ${ }^{3}$ Pakistan Council of Scientific and Industrial Research Laboratories Complex, Lahore, Pakistan
}

Received: 15 January 2017

Accepted: 30 April 2017

\begin{abstract}
The synthesis of growth-promoting compounds for better yield of food crops and benefit to mankind has always been a desire of plant scientists, but the use of hazardous solvents in the process and the low yield of such organic compounds have been major challenges. In this research, naphthyl acetic acid-based compounds were prepared using green chemistry protocols, including microwaves and environmentally friendly solvents. The prepared compounds were chemically characterized to be Schiff bases and ethyl esters. The prepared compounds were assessed for the in vitro growth-promoting capability of Bougainvillea glabra explants on MS basal medium. The concentration range of 1,10 , and $100 \mu \mathrm{M}$ of the compounds was used and the comparison was made with standard thidiazuron (TDZ). The B-10 and B-13 compounds among Schiff bases and B-11 and B-14 compounds among ethyl esters (derived from naphthyl acetic acid moieties) produced significantly better growth response as compared to commercial standard at $1 \mu \mathrm{M}$ concentration in B.glabra explants. Increased catalase and superoxide dismutase levels in explants treated with synthesized compounds indicated stress alleviation in explants through antioxidant enzyme production.
\end{abstract}

Keywords: acetic acid-based compounds, antioxidant enzymatic activities, ethyl esters, green chemistry, Schiff bases, tissue culture

\section{Introduction}

Better plant growth of crop plants has been a major concern of mankind since antiquity. Indole acetic acid

*e-mail: fbareen@gmail.com

is one of the natural plant growth regulators studied in plant sciences for a long time, followed by cytokinins, ethylene, gibberellic acid, and others that were discovered later. Indole acetic acid is responsible for promoting root growth while cytokinins like zeatin are considered specialized for shoot growth [1]. Later on, the attention of scientists was diverted toward commercial production of 
plant growth promoters and soon after they captured the market. These included naphthyl acetic acid (NAA); 2, 4 dichloro phenoxy acetic acid (2,4 D); and thidiazuron (TDZ). These chemicals revolutionized agriculture and are being used extensively for growth-promoting efficacy in plants [2].

Synthetic plant growth regulators are needed to fulfill the food supply chain demand. However, the synthesis of such chemicals requires the use of hazardous solvents and least efficient heating techniques. Hazardous solvents are fatal to aquatic life and create one of the biggest sources of persistent water pollution. In synthetic organic chemistry, solvents like toluene, benzene, and pyridine, etc., are being extensively used, and their carcinogenic nature is affecting the food chains. Similarly, the least efficient heating techniques consume much time and energy but produce little yield [3].

Purine-based synthetic analogues of fluorine containing plant growth regulators have been prepared by various techniques like electrospray reduction of aromatic anion mediator and purines [4-5]. Purine-based compounds have proved to be successful cytokinin analogues and are being used worldwide with growing interest to check the in vivo and in vitro plant growth response [6-7]. Novel cytokinin compounds did not show any negative effect on the growth of roots, while natural cytokinins may decrease root growth. Synthesized plant growth compounds work best in the micromolar and submicromolar range [8-9].

Synthesis of plant growth compounds like any other organic compounds employ hazardous solvents that increase VOCs [10]. They are the cause of autoimmune diseases and are also known for high MAD and SOD activity in humans under long-term exposure, causing serious muscoskeletal, gastrointestinal, cardiovascular, and respiratory problems. Aromatic solvents are a potential hazard for aquatic organisms and also contaminate the food chain [11].

When the conventional method of heating is employed, the reaction time for organic synthesis is 8-10 hours and sometimes more. Indole acetic acid-based Schiff bases and their lanthanide complexes have been synthesized by using less biodegradable and non-environment friendly solvents in low yield, and their chemical nature has been confirmed by various spectroscopic and gravimetric techniques [12]. The use of microwaves and ultrasonics have provided the chemists a new tool for rapid, onepot and high-yield organic synthesis with the additional benefits of energy efficiency and short reaction time [1314].

Another benefit of microwave irradiation is that green solvents like ethanol and acetone can be used in the process, which are safe, environmentally benign, and do not hamper aquatic life [15-16].

A series of new $\mathrm{N}, \mathrm{N}$-diacylhydrazine derivatives have been synthesized by using the energy-efficient techniques of microwave irradiation and environment friendly catalysts in good yield. The synthesized compounds showed excellent herbicidal activity against dicotyledonous weed [17]. Similarly, novel 2, 4 Dichlorophenoxy acetic acid-derived Schiff bases and their lanthanide complexes enhanced the plant growthpromoting activity at $10^{-6} \mathrm{M}$ concentration in wheat seeds. Plant growth activity of the synthesized compounds on wheat seeds indicated that $10^{-6} \mathrm{M}$ concentration of the compounds was the most effective [12].

Micropropagation of Bougainvillea glabra has been extensively studied because of the rapid growth potential of its shoot tips in tissue culture [18]. Thidiazuron is a widely used growth promoter in tissue culture and is commonly used as internal standard because of its efficacy at low concentrations in MS medium [1920].

There is also a growing interest to find the relationship between reactive oxygen species (ROS) and antioxidant response in the growth and development of plant cells [21]. ROS behave as the second messenger in their response in plant tissue growth, development, and regulation [22]. In plants, ROS production is controlled by various nonenzymatic antioxidants and enzymatic defense systems, which is partially performed by SOD that converts $\mathrm{O}_{2}$ to $\mathrm{H}_{2} \mathrm{O}_{2}$ and $\mathrm{CAT}$ that degrades $\mathrm{H}_{2} \mathrm{O}_{2}$ [23]. Superoxide dismutase and catalase are efficient antioxidant enzymes and they are an integral factor in the whole enzymatic process because their combined action prevents cellular degradation caused by $\mathrm{O}_{2}^{-}, \mathrm{H}_{2} \mathrm{O}_{2}$, and $\mathrm{OH}^{-1}$ [24]. During in vitro growth, plant cultures face many extreme conditions, including high sugar and salt concentrations and phytohormonal imbalance, due to which antioxidant activities are required.

This research was aimed at preparing new plant growth promoting organic compounds using green methodologies, including the most efficient heating techniques like microwave irradiation and the use of green solvents like ethanol, chloroform, and acetone, which are easily biodegradable. This is the first study of synthesis of plant growth-promoting compounds from naphthyl acetic acid moieties using green chemistry protocols. Subsequently, the synthesized compounds were assessed for their growth-promoting efficacy and antioxidant enzyme activities in tissue culture-raised explants of Bougainvillea glabra [25].

\section{Material and Methods}

\section{Synthesis of Chemicals Compounds by Using Green Protocols}

Analytical-grade solvents and chemicals were purchased from Merck (Germany) and used as such. All the melting points were determined on a digital melting point apparatus (Gallenkamp England) and were uncorrected. Thin layer chromatography was used to monitor completion of the reaction. Infrared (IR) spectra were recorded on a Tensor 27 by Bruker. ${ }^{1} \mathrm{H}$ NMR spectra were recorded on AVANCE-400 $\mathrm{MHz}$ and ${ }^{13} \mathrm{C} \mathrm{NMR}$ were recorded on AVANCE-300 MHz spectrometer using 
TMS as an internal standard. Microwave irradiation was carried out in specifically designed microwave oven equipped with magnetic stirrer and external reflux condensers (Orient eNNe781JF household microwave oven) that was generating fixed frequency $2450 \mathrm{MHz}$ throughout the required time at multiples of $100-1000 \mathrm{~W}$.

\section{Synthesis of ethyl naphthalen-1-yl-acetate (1)}

A mixture of naphthyl acetic acid $(2 \mathrm{~g})$ and ethanol $(50 \mathrm{ml})$ was heated under microwave irradiation for 5-6 minutes in the presence of 2-3 drops of acetic acid. The reaction mixture was monitored with TLC containing a mixture of chloroform and ethyl acetate. Excess of ethanol was evaporated on the water bath and the mixture was separated with chloroform and water. After extracting the chloroform layer, a pinch of anhydrous $\mathrm{Na}_{2} \mathrm{SO}_{4}$ was added to remove any water. The chloroform layer was heated and it was recovered. Ethyl naphthalen-1-ylacetate was obtained in liquid form and yield was $56 \%$ [26].

Synthesis of 2-(naphthalen-1-yl) acetohydrazide (2)

A mixture of naphthalen-1-ylacetate $(1 \mathrm{mmol})$ and hydrazine hydrate $(1 \mathrm{mmol})$ was irradiated under microwaves in a specially designed oven for 8-10 minutes in the presence of ethanol $(20 \mathrm{ml})$ as solvent. The reaction mixture was monitored for completion using a chloroform and ethyl acetate mixture. Excess of ethanol was evaporated on a water bath. The solid obtained was washed with a dilute solution of acetic acid to remove any excess hydrazine in the mixture. The product was dried in the oven and recrystallized with ethanol. Yield obtained of the synthesized naphthyl acetohydrazide was $73 \%$ [17].

Synthesis of substituted 2-(naphthalene-1-yl) methylidene acetohydrazide (Schiff bases 3)

An equimolar quantity of naphthalen-1-acetohydrazide (1 mmol) and substituted aldehydes (1 mmol) having 2-3 drops of acetic acid was irradiated under microwaves in an oven for 4-6 minutes in the presence of ethanol $(20 \mathrm{ml})$ as solvent. The reaction mixture was monitored for completion using a chloroform and ethyl acetate mixture. Excess of ethanol was evaporated on a water bath and the solid obtained was washed with cold ethanol. The product was dried in an oven and recrystallized with ethanol [27]. Compound B-01, B-04, B-10, B-13, B-16, B-21 were synthesized by using this methodology.

Synthesis of substituted ethyl

$$
\text { (naphthalen-1-ylacetyl) hydrazinyl acetate (4) }
$$

Schiff bases of methylidene acetohydrazide $(1 \mathrm{mmol})$ reacted with ethyl chloro acetate $(2 \mathrm{mmol})$ in the presence of anhydrous $\mathrm{K}_{2} \mathrm{CO}_{3}(5 \mathrm{mmol})$ It was irradiated in a microwave oven for 3-5 minutes using acetone $(25 \mathrm{ml})$ as a solvent. The reaction mixture was monitored for completion using a chloroform and ethyl acetate mixture. Excess of acetone was evaporated and the solid obtained was washed with cold ethanol. The product was dried in

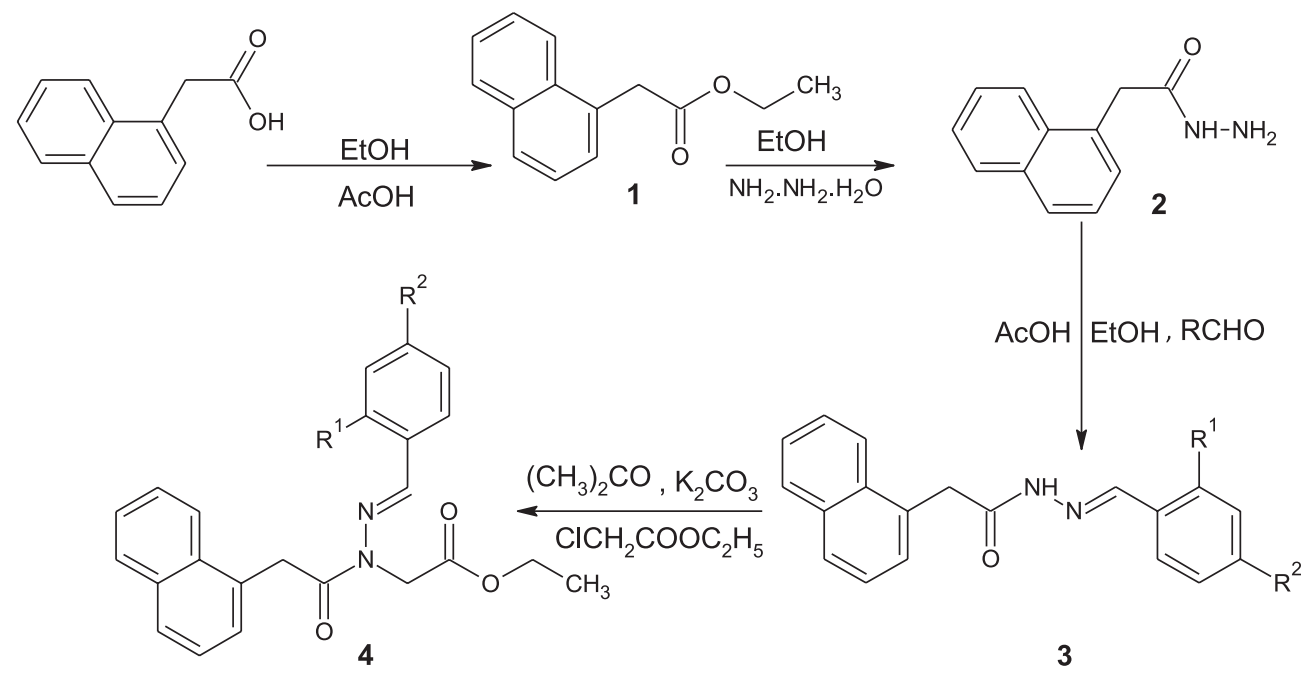

B-02, B-05, B-11, B-14, B-17, B-22

B-01, B-04, B-10, B-13, B-16, B-21

\begin{tabular}{|l|c|c|c|c|c|c||c|c|c|c|c|c|c|}
\hline & $\mathbf{B}-02$ & $\mathbf{B}-05$ & $\mathbf{B}-11$ & $\mathbf{B}-14$ & $\mathbf{B}-17$ & $\mathbf{B}-22$ & & $\mathbf{B}-01$ & $\mathbf{B}-04$ & $\mathbf{B}-10$ & $\mathbf{B}-13$ & $\mathbf{B}-16$ & $\mathbf{B}-21$ \\
\hline $\mathrm{R}$ & $\mathrm{C}_{6} \mathrm{H}_{5}$ & $\mathrm{C}_{6} \mathrm{H}_{5}$ & $\mathrm{C}_{6} \mathrm{H}_{5}$ & $\mathrm{C}_{6} \mathrm{H}_{5}$ & $\mathrm{C}_{6} \mathrm{H}_{5}$ & $\mathrm{C}_{6} \mathrm{H}_{5}$ \\
\hline $\mathrm{R}^{1}$ & $\mathrm{H}$ & $\mathrm{Cl}$ & $\mathrm{NO}_{2}$ & $\mathrm{H}$ & $\mathrm{H}$ & $\mathrm{H}$ & $\mathrm{C}_{6} \mathrm{H}_{5}$ & $\mathrm{C}_{6} \mathrm{H}_{5}$ & $\mathrm{C}_{6} \mathrm{H}_{5}$ & $\mathrm{C}_{6} \mathrm{H}_{5}$ & $\mathrm{C}_{6} \mathrm{H}_{5}$ & $\mathrm{C}_{6} \mathrm{H}_{5}$ \\
\hline $\mathrm{R}^{2}$ & $\mathrm{Cl}$ & $\mathrm{H}$ & $\mathrm{H}$ & $\mathrm{H}$ & $\mathrm{OCH}_{3}$ & $\mathrm{NO}_{2}$ \\
\cline { 5 - 12 } & $\mathrm{R}$ & $\mathrm{H}$ & $\mathrm{Cl}$ & $\mathrm{NO}_{2}$ & $\mathrm{H}$ & $\mathrm{H}$ & $\mathrm{H}$ & $\mathrm{H}$ & $\mathrm{H}$ & $\mathrm{OCH}_{3}$ & $\mathrm{NO}_{2}$ \\
\hline
\end{tabular}

Fig. 1. Scheme of synthesis of organic compounds using green protocols. 
an oven and recrystallized with ethanol [17, 28]. (Scheme of synthesis is shown in Fig. 1.). Compound B-02, B-05, B-11, B-14, B-17, B-22 were synthesized by using this methodology.

\section{Biological Activities of Compounds}

All prepared compounds were dissolved in the minimum possible quantity of dimethyl sulfoxide (DMSO) and diluted with distilled sterilized water to make a stock solution of $10 \mathrm{mM}$, which was further diluted to prepare other concentrations of 1,10 , and $100 \mu \mathrm{M}$.

Fresh branches of Bougainvillea glabra $(10 \mathrm{~cm})$ were collected from University of the Punjab, Lahore, Pakistan. They were kept under running tap water for half an hour. Shoot meristematic tissues of B. glabra were cut up into $1-\mathrm{cm}$ explants having nodal region and a uniform biomass. The impact of prepared compounds was observed in stimulating growth using the tissue culture technique. The explants were surface-sterilized in $70 \%$ ethanol for one minute and in sodium hypochlorite for 8-10 minutes having 1-2 drops of Tween 20. Then they were washed with distilled autoclaved water thrice to remove any residues of chemicals before culturing.

Murashige and Skoog (MS) basal medium supplemented with TDZ, NAA, and synthesized compounds at 1,10 , and $100 \mu \mathrm{M}$ concentrations with $30 \mathrm{gL}^{-1}$ sugar was used to asses plant growth using $7.4 \mathrm{gL}^{-1}$ of agar as a solidifying agent. The $\mathrm{pH}$ of medium was adjusted between 5.7-5.8 before the addition of agar. After autoclaving, the compounds with their relevant concentrations were added before pouring the medium into $30 \mathrm{ml}$ test tubes [18]. The test tubes were inoculated with the prepared explants of Bougainvillea glabra under completely aseptic conditions and placed in a growth chamber at $25^{\circ} \mathrm{C}$ under 16 hours light and 8 hours of dark. The light intensity was maintained at 2,000-3,000 lux. Five replicates of each treatment were taken and growth initiation and plantlet formation was recorded after 2-3 weeks. The biomass of the explants was recorded at three weekly intervals [19].

\section{Extraction of Antioxidant Enzymes}

Approximately $100 \mathrm{mg}$ of fresh leaf tissue was randomly taken from cultured plants, frozen in liquid nitrogen, and stored at $-80^{\circ} \mathrm{C}$ until further analysis. Extraction of SOD and CAT was performed as described by $\mathrm{He}$ et al. (2001) with minor modifications. Briefly frozen leaves were mixed with $3 \mathrm{ml}$ of $150 \mathrm{mM}$ cold phosphate buffer ( $\mathrm{pH} 7.0)$ with a mortar and pestle and centrifuged at $12,000 \mathrm{rpm}$ for 20 minutes at $4^{\circ} \mathrm{C}$ in a temperature-controlled centrifuge [29]. The extract was used for estimating enzyme activities.

\section{Estimating Catalase (CAT) Activity}

CAT activity was determined based on the oxidation of $\mathrm{H}_{2} \mathrm{O}_{2}$ using the method of Chance and Maehly (1955) with little modification. The reaction solution $(3 \mathrm{ml})$ contained $50 \mathrm{mM}$ phosphate buffer ( $\mathrm{pH} 7.0), 45 \mathrm{mM} \mathrm{H}_{2} \mathrm{O}_{2}$, and $100 \mu \mathrm{l}$ of extracted solution. The reaction was started by adding the enzyme solution. Changes in absorbance at $240 \mathrm{~nm}$ were calculated after every 10 seconds for $60-80$ seconds using a Shimadzu UV 1800 Spectrophotometer. One unit of CAT activity was defined as the absorbance change of 0.01 per min [30].

\section{Estimating Superoxide Dismutase (SOD) Activity}

SOD activity was estimated by the method of Giannopolitis and Ries (1977) with minor modifications. The reaction solution $(3 \mathrm{ml})$ contained $50 \mathrm{mM}$ phosphate buffer ( $\mathrm{pH}$ 7.8), $60 \mu \mathrm{M}$ riboflavin, $195 \mathrm{mM}$ methionine, 3 uM EDTA, $1.125 \mathrm{mM}$ nitro blue tetrazolium, and $100 \mu \mathrm{L}$ of extracted enzyme solution. A solution containing no enzyme was used as the control. Test tubes were irradiated under fluorescent light at $100 \mu \mathrm{mol} . \mathrm{m}^{-2} \mathrm{~s}^{-1}$ for 20 minutes and then placed in the dark for 10 minutes. The absorbance of each solution was read at $560 \mathrm{~nm}$ and one unit of enzyme activity was defined as the amount of enzyme that would inhibit 50\% of NBT photo reduction [31].

\section{Results and Discussion}

\section{Chemical Characterization of the Prepared Compounds}

Compounds synthesized using green protocols include Schiff bases and their corresponding ethyl esters. Spectroscopic detail of Schiff bases - including molecular mass, melting point, IR, and Proton NMR - is given below:

1. $\quad N^{\prime}$-[(4-Chlorophenyl) methylidene]-2-(naphthalen-1yl) acetohydrazide (B-01):

Yellowish white solid, RT 4 min, yield $89 \%$, mp $234-236^{\circ} \mathrm{C}$, IR (KBr): $v$ 3273.81, 3040.22, 2957.21, 1667.04, 1556.60, 1434.11, 1342.20, 1231.07,1077.69, $746.46 \mathrm{~cm}^{-1}$; ${ }^{1} \mathrm{H}$ NMR (400 MHz, $\left.\mathrm{CDCl}_{3}\right) \delta: 8.753$ (s, 1H, NH), 8.037 (s, 1H, CH), 8.052-7.769 (m, 5H, $\mathrm{ArH}), 7.609-7.429$ (m, 6H, $\mathrm{ArH}), 4.518\left(\mathrm{~s}, 2 \mathrm{H}, \mathrm{CH}_{2}\right)$.

2. N'-[(2-Chlorophenyl) methylidene]-2-(naphthalen-1yl) acetohydrazide (B-04):

White solid, RT (Mw) 5 min, yield $87 \%$, mp $182^{\circ} \mathrm{C}$, IR (KBr): v 3277.96, 3002.84, 2953.13, 1664.48, 1550.48, 1416.90, 1350.94, 1213.36, 1054.49, $732.18 \mathrm{~cm}^{-1}$. ${ }^{1} \mathrm{H}$ NMR (400 MHz, $\left.\mathrm{CDCl}_{3}\right) \delta: 8.699$ (s, $\left.1 \mathrm{H}, \mathrm{NH}\right)$, 8.150 (s, 1H, CH), 8.088 (d, $J=6.3 \mathrm{~Hz}, 1 \mathrm{H}, \mathrm{ArH})$, 7.945-7.839 (m, 4H, ArH), 7.780-7.273 (m, 6H, ArH), $4.529\left(\mathrm{~s}, 2 \mathrm{H}, \mathrm{CH}_{2}\right)$.

3. 2-(Naphthalen-1-yl)- $N$ '-[2-nitrophenyl) methylidene] acetohydrazide (B-10):

Yellowish white solid, RT (Mw) 5 min, yield 85\%, $\mathrm{mp} \quad 222-224^{\circ} \mathrm{C}$, IR (KBr): v 3176.79, 3005.44, 2976.29, 1629.83, 1512.96, 1455.21, 1368.66, 
1222.91,1061.24 $\mathrm{cm}^{-1}$. ${ }^{1} \mathrm{H}$ NMR $\left(400 \mathrm{MHz}, \mathrm{CDCl}_{3}\right)$ $\delta: 9.864(\mathrm{~s}, 1 \mathrm{H}, \mathrm{NH}), 7.809$ (s, 1H, CH), 7.633-7.331 $(\mathrm{m}, 5 \mathrm{H}, \operatorname{ArH}), 6.943-6.664(\mathrm{~m}, 5 \mathrm{H}, \mathrm{ArH}), 6.664$ (s, 1H, ArH), 4.127 (s, 2H, $\mathrm{CH}_{2}$ ).

4. 2-(Naphthalen-1-yl)- $N$ '-[phenyl methylidene] acetohydrazide (B-13):

White solid, RT (Mw) 4 min, yield $90 \%, \mathrm{mp} 220^{\circ} \mathrm{C}$, IR (KBr): $v$ 3207.98, 3075.23, 2914.80, 1669.58, 1562.08, $1394.88,1234.43,1133.44 \mathrm{~cm}^{-1}{ }^{1} \mathrm{H}$ NMR $(400 \mathrm{MHz}$, $\left.\mathrm{CDCl}_{3}\right) \delta: 10.104(\mathrm{~s}, 1 \mathrm{H}, \mathrm{NH}), 8.857(\mathrm{~s}, 1 \mathrm{H}, \mathrm{CH}), 8.115$ $(\mathrm{d}, J=8.1 \mathrm{~Hz}, 1 \mathrm{H}, \operatorname{Ar} H), 7.886-7.639$ (m, 5H, $\operatorname{Ar} H)$, 7.671-7.639 (m, 2H, ArH), 7.548-7.390 (m, 4H, ArH), $4.538\left(\mathrm{~s}, 2 \mathrm{H}, \mathrm{CH}_{2}\right)$.

5. $\quad$ '-[4-Methoxyphenyl) methylidene]-2-(naphthalen-1yl) acetohydrazide (B-16):

White solid, RT (M) 6 min, yield $84 \%, \mathrm{mp} 180^{\circ} \mathrm{C}$, IR (KBr): $v$ 3218.67, 3045.44, 2921.21, 1662.22, 1554.06, 1372.62, 1255.68, $1069.52 \mathrm{~cm}^{-1} .{ }^{1} \mathrm{H}$ NMR $\left(400 \mathrm{MHz}, \mathrm{CDCl}_{3}\right) \delta: 9.35(\mathrm{~s}, 1 \mathrm{H}, \mathrm{NH}), 8.37(\mathrm{~s}, 1 \mathrm{H}, \mathrm{CH})$, 7.99-7.832 (m, 1H, ArH), 7.657-7.391 (m, 4H, ArH), 7.256-7.139 (m, 6H, ArH), $4.538\left(\mathrm{~s}, 2 \mathrm{H}, \mathrm{CH}_{2}\right), 3.71$ (s, $\left.3 \mathrm{H}, \mathrm{OCH}_{3}\right)$.

6. 2-(Naphthalen-1-yl)- $N$ '-[4-nitrophenyl) methylidene] acetohydrazide (B-21):

Yellowish white solid, RT ${ }_{(\mathrm{MW})} 5 \mathrm{~min}$, yield $81 \%$, mp $284^{\circ} \mathrm{C}$, IR (KBr): $v 3194.47,2954.08,2896.10,1669.91$, 1386.35, 1244.12, 1367.81, $1109.59 \mathrm{~cm}^{-1} .1 \mathrm{H}$ NMR $\left(400 \mathrm{MHz}, \mathrm{CDCl}_{3}\right) \delta: 8.280(\mathrm{~s}, 1 \mathrm{H}, \mathrm{NH}), 7.872(\mathrm{~s}, 1 \mathrm{H}$, $\mathrm{CH}), 7.845-7.736(\mathrm{~m}, 5 \mathrm{H}, \mathrm{ArH}), 7.542-7.434$ (m, 5H, $\mathrm{ArH}), 6.742(\mathrm{~s}, 1 \mathrm{H}, \mathrm{ArH}), 4.566\left(\mathrm{~s}, 2 \mathrm{H}, \mathrm{CH}_{2}\right)$.

Spectroscopic detail of new ethyl esters - including molecular mass, melting point, IR, and Proton NMR - is given below:

1. Ethyl [2-(4-Chlorobenzylidene)-1-(naphthalen-1ylacetyl) hydrazinyl] acetate (B-02):

Yellowish white solid, RT ${ }_{\text {(M) }} 3$ min, yield $85 \%$, mp $154-156^{\circ} \mathrm{C}$, IR (KBr): v 3124.06, 2912.70,1735.69, $1677.20, \quad 1425.36, \quad 1343.92,1224.64, \quad 1092.69$, $646.61 \mathrm{~cm}^{-1} .{ }^{1} \mathrm{H}$ NMR (400 MHz, $\left.\mathrm{CDCl}_{3}\right) \delta: 8.026$ $(\mathrm{d}, J=6.0 \mathrm{~Hz}, 1 \mathrm{H}, \operatorname{Ar} H), 7.929(\mathrm{~s}, 1 \mathrm{H}, \mathrm{CH})$, 7.856-7.833 (m, 1H, ArH), 7.510-7.290 (m, 9H, ArH), 4.813 (s, 2H, $\left.\mathrm{CH}_{2}\right), 4.688$ (s, 2H, $\left.\mathrm{CH}_{2}\right), 4.19$ (q, $J=5.4$ $\left.\mathrm{Hz}, 2 \mathrm{H}, \mathrm{CH}_{2}\right), 1.220$ (t, $J=5.4 \mathrm{HZ}, 3 \mathrm{H}, \mathrm{CH}_{3}$ ).

2. Ethyl [2-(2-Chlorobenzylidene)-1-(naphthalen-1ylacetyl) hydrazinyl acetate (B-05):

White solid, RT ${ }_{(\mathrm{MW})} 4 \mathrm{~min}$, yield $87 \%$, mp $182^{\circ} \mathrm{C}$, IR (KBr): v 3136.42, 2934.45.70,1727.18, 1684.98, 1415.49, 1344.54, 1271.56, 1027.19, $624.41 \mathrm{~cm}^{-1} .{ }^{1} \mathrm{H}$ NMR $\left(400 \mathrm{MHz}, \mathrm{CDCl}_{3}\right) \delta$ : $18.026(\mathrm{~d} J=6.0 \mathrm{~Hz}, 1 \mathrm{H}$, $\operatorname{ArH}), 7.929(\mathrm{~s}, 1 \mathrm{H}, \mathrm{CH})$ 7.856-7.75 (m, 1H, ArH), 7.517-7.7248 (m, 9H, ArH), 4.855 (s, 2H, $\left.\mathrm{CH}_{2}\right), 4.704$ (s, $2 \mathrm{H}, \mathrm{CH}_{2}$ ), 4.217 (q, $J=5.4 \mathrm{~Hz}, 2 \mathrm{H}, \mathrm{CH}_{2}$ ) 1.241 (t, $J=5.4 \mathrm{~Hz}, 3 \mathrm{H}, \mathrm{CH}_{3}$ ).

3. Ethyl 1-[(Naphthalen-1-yl) acetyl]-2-[(2-nitrophenyl) methylidene] hydrazinyl acetate (B-11):

Yellowish white solid, RT (MW) 4 min, yield 85\%, $\mathrm{mp} 144^{\circ} \mathrm{C}$, IR (KBr): v 3114.65, 2920.09,1733.77, $1674.35,1424.77,1383.27,1228.42,1034.21 \mathrm{~cm}^{-1}$. ${ }^{1} \mathrm{H}$ NMR (400 MHz, $\left.\mathrm{CDCl}_{3}\right) \delta: 8.092(\mathrm{~s}, 1 \mathrm{H}, \mathrm{CH})$,
8.036-7.990 (m, 1H, ArH), 7.869-7.443 (m, 3H, ArH), 7.502-7.407 (m, 7H, ArH) $4.858\left(\mathrm{~s}, 2 \mathrm{H}, \mathrm{CH}_{2}\right), 4.680$ $\left(\mathrm{s}, 2 \mathrm{H}, \mathrm{CH}_{2}\right), 4.24\left(\mathrm{q}, J=5.4 \mathrm{~Hz}, 2 \mathrm{H}, \mathrm{CH}_{2}\right), 1.272$ $\left(\mathrm{t}, J=5.4 \mathrm{~Hz}, 3 \mathrm{H}, \mathrm{CH}_{3}\right) \cdot{ }^{13} \mathrm{C} \mathrm{NMR}\left(\mathrm{CDCl}_{3}, 300 \mathrm{MHz}\right)$ $\delta: 14.09,37.62,42.80,62.08,123.90,124.91,125.51$, $125.66,126.23,127.52,127.71 .128 .58,128.75,129.23$, $130.05,131.64,132.21,133.49,133.86 .135 .19,148.13$, $166.73,173.15$.

4. Ethyl [(2-Benzylidene-1-(naphthalen-1-ylacetyl) hydrazinyl] acetate (B-14):

White solid, RT (MW) 3 min, yield $89 \%, \mathrm{mp} 90^{\circ} \mathrm{C}$, IR (KBr): $v$ 3004.83, 2923.42,1735.65, 1674.13, $1422.15,1347.32,1222.43,1027.36 \mathrm{~cm}^{-1} .1 \mathrm{H}$ NMR $\left(400 \mathrm{MHz}, \mathrm{CDCl}_{3}\right) \delta: 8.055(\mathrm{~d}, J=7.5 \mathrm{~Hz}, 1 \mathrm{H}, \mathrm{ArH})$, 7.85-7.75 (m, 2H, ArH), 7.539 (s, 1H, CH), 7.632-7.345 (m,9H, ArH), 4.828(s, 2H, $\left.\mathrm{CH}_{2}\right), 4.718\left(\mathrm{~s}, 2 \mathrm{H}, \mathrm{CH}_{2}\right), 4.191$ (q, $J=7.2 \mathrm{~Hz}, 2 \mathrm{H}, \mathrm{CH}_{2}$ ), $1.218\left(\mathrm{t}, J=7.2 \mathrm{~Hz}, 3 \mathrm{H}, \mathrm{CH}_{3}\right.$ ).

5. Ethyl \{2-[(4-Methoxyphenyl) methylidene]-1[(naphthalen-1-yl) acetyl] hydrazinyl $\}$ acetate (B-17): White solid, RT (Mw) 5 min, yield $81 \%$, mp $96^{\circ} \mathrm{C}$, IR (KBr): v 3014.12, 2993.74, 1735.64, 1672.31, 1421.71, 1345.09, 1217.24, $1030.81 \mathrm{~cm}^{-1} .{ }^{1} \mathrm{H}$ NMR $(400 \mathrm{MHz}$, $\left.\mathrm{CDCl}_{3}\right) \delta: 8.055(\mathrm{~d}, J=7.5 \mathrm{~Hz}, 1 \mathrm{H}, \mathrm{ArH}), 7.846-7.735$ (m, 4H, ArH), 7.561-6.859 (m, 7H, ArH), 4.808 (s, $\left.2 \mathrm{H}, \mathrm{CH}_{2}\right), 4.697$ (s, 2H, $\left.\mathrm{CH}_{2}\right), 4.182$ (q, $J=5.4 \mathrm{~Hz}, 2 \mathrm{H}$, $\left.\mathrm{CH}_{2}\right), 3.818\left(\mathrm{~s}, 3 \mathrm{H}, \mathrm{OCH}_{3}\right) 1.212\left(\mathrm{t}, \mathrm{J}=5.4 \mathrm{~Hz}, 3 \mathrm{H}, \mathrm{CH}_{3}\right)$.

6. Ethyl $\{1-[($ Naphthalen-1-yl) acetyl]-2-[(4-nitrophenyl) methylidene] hydrazinyl $\}$ acetate (B-22):

Yellowish white solid, RT (Mw) 4 min, yield 90\%, $\mathrm{mp} 138^{\circ} \mathrm{C}$, IR (KBr): v 3136.45, 2985.66, 1731.91, $1681.76,1416.68,1341.82,1223.40,1024.85 \mathrm{~cm}^{-1}$. ${ }^{1} \mathrm{H}$ NMR (400 MHz, $\left.\mathrm{CDCl}_{3}\right) \delta: 8.17-8.14(\mathrm{~m}, 2 \mathrm{H}$, $\operatorname{ArH}), 8.032-7.755$ (m, 4H, ArH), 7.537-7.382 (m, 6H, $\mathrm{ArH}), 4.845\left(\mathrm{~s}, 2 \mathrm{H}, \mathrm{CH}_{2}\right), 4.705\left(\mathrm{~s}, 2 \mathrm{H}, \mathrm{CH}_{2}\right), 4.212$ (q, $\left.J=5.4 \mathrm{~Hz}, 2 \mathrm{H}, \mathrm{CH}_{2}\right), 1.240\left(\mathrm{t}, J=5.4 \mathrm{~Hz}, 3 \mathrm{H}, \mathrm{CH}_{3}\right.$ ). ${ }^{13} \mathrm{C}$ NMR $\left(\mathrm{CDCl}_{3}, 300 \mathrm{MHz}\right) \delta: 14.09,37.53,42.74$, 62.01, 123.76, 124.04 (3C), 125.45, 125.71, 126.24, $127.45,127.67$ (2C), 127.78, 128.82, 131.44, 132.14, 133.89, 136.30, 140.09, 148.29, 166.82, 173.09.

In IR spectra $-\mathrm{C}=\mathrm{N}$ stretching, which is one of the two major peaks of Schiff bases, is expected to appear within the range of $1,620-1,690 \mathrm{~cm}^{-1}$ and $\mathrm{C}=\mathrm{C}$ stretching at about $1,500-1,560 \mathrm{~cm}^{-1}$. In the IR data of our synthesized compounds, both can be found at $1,629-1,669 \mathrm{~cm}^{-1}$ and 1,515-1,556 $\mathrm{cm}^{-1}$, respectively [32]. The presence of a singlet due to $-\mathrm{NH}$ is expected at $\delta 8.80-9.70$ and it is also present in the range $\delta$ 8.280-10.014 in ${ }^{1} \mathrm{H}$ NMR data of our synthesized Schiff bases [33-34]. Similarly, carbonyl carbon $-\mathrm{C}=\mathrm{O}$ major peak in IR spectra of synthesized ethyl esters in the range $1,727-1,735 \mathrm{~cm}^{-1}$ (ideal value is $1,720-1,750 \mathrm{~cm}^{-1}$ ) confirms acetate moiety. Ethyl acetate moiety can also be confirmed by the presence of a triplet due to $\mathrm{CH}_{3}$ at $\delta$ 1.212-1.240 and a quartet due to $\mathrm{CH}_{2}$ group at $\delta 4.179-4.237$ in ${ }^{1} \mathrm{H}$ NMR spectral data [35].

It is worth noting that there is one extra singlet peak in the case of B-16 (Schiff base) at $\delta 4.01$ and in $\mathrm{B}-17$ (ethyl ester) at $\delta 3.818$. This is due to the presence of three extra proton of $-\mathrm{OCH}_{3}$ in both compounds, 


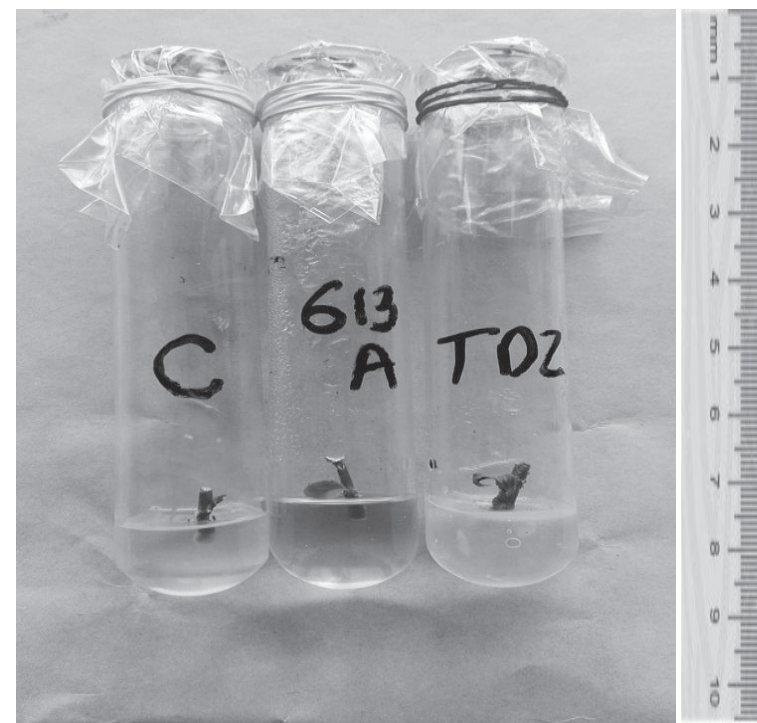

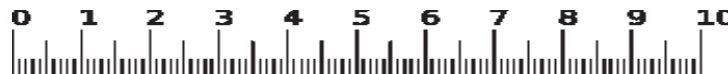

Fig. 2. Growth response of Bougainvillea explants treated with $\mathrm{B}-13$ at $1 \mu \mathrm{M}$ after 14 days (test tube $\mathrm{C}$ indicates control, test tube 613 A contains compound B-13, and test tube TDZ contains commercial standard).

which is present at para (4th) position of its precursor benzaldehyde. This peak is not present in any other Schiff base or ethyl ester.

${ }^{13} \mathrm{C}$ NMR spectra of representative compound (B-11) of this series shows that there is a peak at $\delta 14.09 \mathrm{ppm}$ which is due to carbon of methyl group in ethyl acetate moiety. At $\delta 37.62 \mathrm{ppm}$ there is peak due to carbon of $\mathrm{CH}_{2}$ group attached with naphthalene ring. Then there is peak at $\delta 42.80$ ppm which is due to carbon neighbored with nitrogen followed by a peak at $\delta 62.08 \mathrm{ppm}$ which is due to carbon of $-\mathrm{CH}_{2}$ group of ethyl esters. From $\delta$
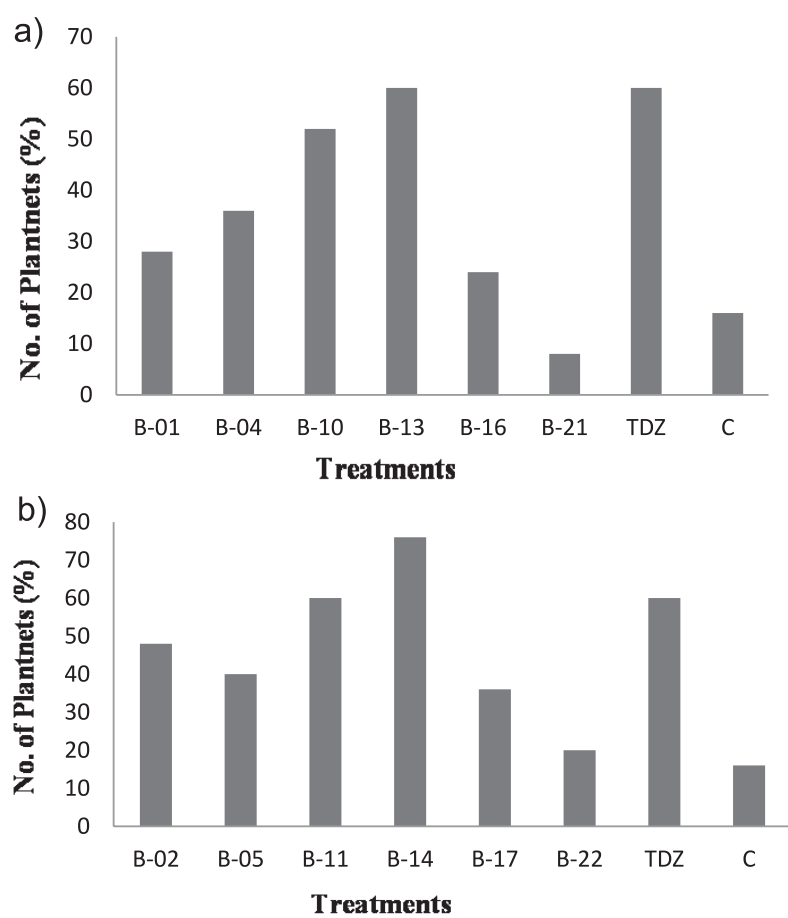

Fig. 3. Number of plantlets produced by the Bougainvillea explants in response to the applied Schiff bases a) and ethyl esters b).

123.90- $133.86 \mathrm{ppm}$ there are carbon of aromatic regions after that there are two peaks at $\delta 135.19$ and $148.13 \mathrm{ppm}$ which are due to carbons directly attached with nitrogen via single and double bond. Carbon attached nitrogen with double bond is characteristic peak of schiff base. Finally, there are two peaks one is due to $-\mathrm{C}=\mathrm{O}$ group of ester at $\delta 166.73 \mathrm{ppm}$ and $-\mathrm{C}=\mathrm{O}$ group attached with nitrogen at $\delta 173.15$.

Table 1. Shoot biomass of Bougainvillea glabra explants after treatment with different synthesized Schiff bases.

\begin{tabular}{|c|c|c|c|c|c|}
\hline \multirow{2}{*}{ Compound } & \multicolumn{4}{|c|}{ Shoot biomass (mg) after days: } & \multirow{2}{*}{ Mean } \\
\hline & 0 & 7 & 14 & 21 & \\
\hline B-01 & $124.03 \pm 0.15 \mathrm{a}$ & $126.97 \pm 0.18 b$ & $130.53 \pm 0.15 \mathrm{c}$ & $132.83 \pm 0.18 \mathrm{~cd}$ & $128.59 \pm 1.02 \mathrm{~A}$ \\
\hline B-04 & $123.73 \pm 0.12 \mathrm{a}$ & $127.83 \pm 0.12 b$ & $129.33 \pm 0.09 \mathrm{c}$ & $131.93 \pm 0.18 \mathrm{bc}$ & $128.21 \pm 0.90 \mathrm{~A}$ \\
\hline B -10 & $123.33 \pm 0.18 \mathrm{a}$ & $127.40 \pm 0.26 b$ & $137.50 \pm 0.15 \mathrm{e}$ & $145.60 \pm 0.25 \mathrm{~g}$ & $133.46 \pm 2.63 \mathrm{~B}$ \\
\hline B -13 & $123.73 \pm 0.09 a$ & $129.53 \pm 0.15 \mathrm{c}$ & $142.17 \pm 0.19 f$ & $146.17 \pm 0.24 \mathrm{~g}$ & $135.40 \pm 2.75 \mathrm{C}$ \\
\hline B -16 & $123.53 \pm 0.07 \mathrm{a}$ & $125.30 \pm 0.12 \mathrm{ab}$ & $128.53 \pm 0.18 \mathrm{c}$ & $133.13 \pm 0.20 \mathrm{~d}$ & $127.63 \pm 1.10 \mathrm{~A}$ \\
\hline B -21 & $123.70 \pm 0.15 \mathrm{a}$ & $127.10 \pm 0.10 \mathrm{~b}$ & $130.10 \pm 0.21 \mathrm{c}$ & $133.67 \pm 0.19 \mathrm{~d}$ & $128.64 \pm 1.11 \mathrm{~A}$ \\
\hline TDZ & $125.33 \pm 0.09 \mathrm{ab}$ & $131.13 \pm 0.18 b c$ & $134.33 \pm 0.42 \mathrm{~d}$ & $145.70 \pm 0.49 \mathrm{~g}$ & $134.13 \pm 2.24 \mathrm{BC}$ \\
\hline $\mathrm{C}$ & $124.00 \pm 0.95 \mathrm{a}$ & $127.10 \pm 1.75 b$ & $129.07 \pm 2.12 \mathrm{c}$ & $134.47 \pm 5.42 \mathrm{~d}$ & $128.66 \pm 1.74 \mathrm{~A}$ \\
\hline Mean & $123.93 \pm 0.16 \mathrm{~A}$ & $127.80 \pm 0.40 \mathrm{~B}$ & $132.70 \pm 0.98 \mathrm{C}$ & $137.94 \pm 1.40 \mathrm{D}$ & \\
\hline
\end{tabular}

Means sharing similar letters in a row or in a column are statistically non-significant $(\mathrm{P}>0.05)$. Lowercase letters represent comparison among compounds and growth time while capital letters indicate overall mean according to DMRT. 


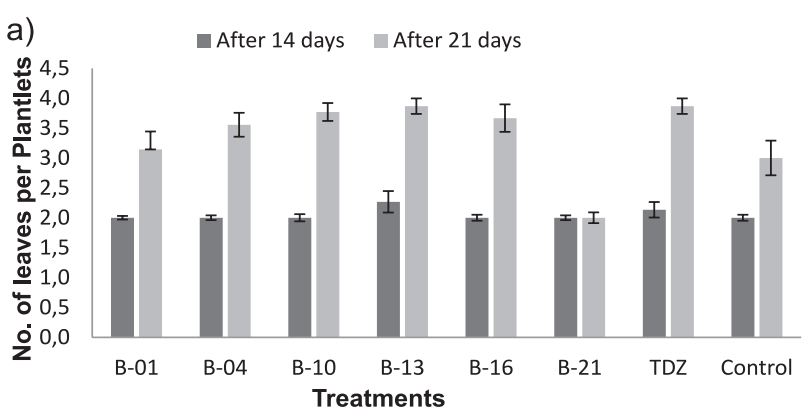

b)

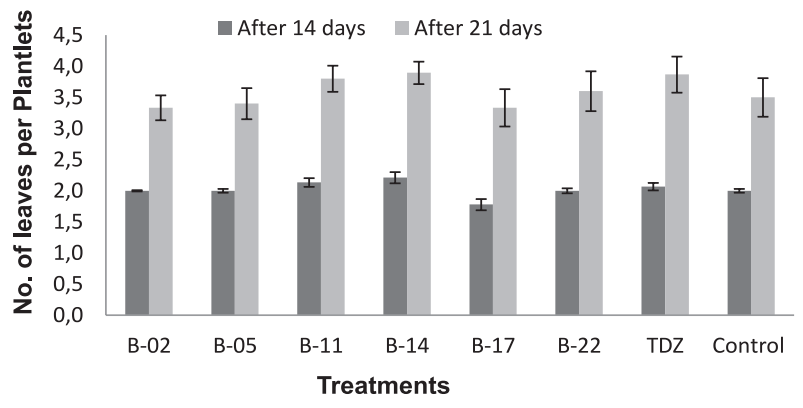

Fig. 4. Number of leaves per plantlet produced in Bougainvillea explants in response to Schiff bases a) and ethyl esters b).

\section{Growth Response of Bougainvillea glabra Explants to Synthesized Compounds}

Biological assays were carried out with the synthesized Schiff bases and ethyl esters at 1, 10, and $100 \mu \mathrm{M}$ concentration for their phytohormonal ability to induce growth and development in Bougainvillea glabra. The tissue culture technique of culturing explants was used against standard TDZ at the same concentration and control (without any growth compound) using MS basal medium.

None of the compounds was able to trigger any growth response at $100 \mu \mathrm{M}$ concentration in Bougainvillea glabra. Only the compound B-14 stimulated growth at the $10 \mu \mathrm{M}$ concentration. Significant growth was observed using $1 \mu \mathrm{M}$ concentration of the synthesized compounds. Naik et al. have observed the effect of 2,4-Dichlorophenoxyacetic acid and its lanthanide complexes [12] and Indole 3 acetic acid-derived Schiff base and its lanthanide complexes on the germination and growth activity on wheat seeds, and found the best results at $10^{-6} \mathrm{M}$ concentration. However, Podlesakova et al. [8] have observed the good impact of some novel cytokinin derivatives on leaf emergence and lateral root branching in the nano molar range of concentrations in Arabidopsis and maize.

The shoot biomass of $B$. glabra was the highest in the case of the Schiff base B-13 as shown in Fig. 2 and was comparable to TDZ. However, growth only became significant after 14 days (Table 1). The mean shoot biomass was in the order of B-13>TDZ>B-10. These compounds triggered some hormonal response probably due to their small size and low molecular mass while mimicking the receptor [36]. All other compounds showed significantly less biomass as compared to TDZ. In general, the biomass increased with increasing time. The number of plantlets and greater number of leaves per plantlet also confirmed the overall biomass of the explants (Figs 3a and 4a).

In the case of ethyl esters, B-02, B-11, and B-14 synthesized compounds at $1 \mu \mathrm{M}$ concentration, producing significantly better biomass. As shown in Table 2, the compound B-14 produced significantly higher biomass after 14 and 21 days than the commercial standard TDZ and the control. The biomass produced by B-14 at $1 \mu \mathrm{M}$ concentration was considerably higher than other synthesized compounds of the same series. Similarly, the compound B-11 also proved to be a good promoter of biomass after 14 and 21 days. Biomass produced by all synthesized compounds was higher than the control (Table 2). The biomass production was in the order of $\mathrm{B}-14>\mathrm{B}-11>\mathrm{B}-02>\mathrm{TDZ}$. Only the compound B-14

Table 2. Shoot biomass of Bougainvillea glabra explants after treatment with the different synthesized ethyl esters.

\begin{tabular}{|c|c|c|c|c|c|}
\hline \multirow{2}{*}{ Compound } & \multicolumn{4}{|c|}{ Shoot biomass (mg) after days: } & \multirow{2}{*}{ Mean } \\
\hline & 0 & 7 & 14 & 21 & \\
\hline B-02 & $124.10 \pm 0.32 \mathrm{a}$ & $133.77 \pm 0.24 d$ & $137.20 \pm 0.40 \mathrm{e}$ & $143.10 \pm 0.25 \mathrm{~g}$ & $134.54 \pm 2.08 \mathrm{~B}$ \\
\hline B-05 & $124.07 \pm 0.22 \mathrm{a}$ & $128.40 \pm 0.45 b$ & $131.00 \pm 1.65 \mathrm{c}$ & $135.27 \pm 3.17 \mathrm{~d}$ & $129.68 \pm 1.45 \mathrm{~A}$ \\
\hline B-11 & $123.67 \pm 0.48 \mathrm{a}$ & $129.00 \pm 1.67 b c$ & $139.30 \pm 1.86 f$ & $147.17 \pm 1.73 \mathrm{~h}$ & $134.78 \pm 2.82 \mathrm{~B}$ \\
\hline B-14 & $123.70 \pm 0.06 \mathrm{a}$ & $131.20 \pm 1.55 \mathrm{c}$ & $142.93 \pm 0.85 \mathrm{~g}$ & $150.17 \pm 4.07 \mathrm{i}$ & $137.00 \pm 3.23 \mathrm{~B}$ \\
\hline B-17 & $123.30 \pm 0.21 \mathrm{a}$ & $127.63 \pm 2.34 b$ & $132.20 \pm 3.70 \mathrm{c}$ & $136.53 \pm 3.39 \mathrm{de}$ & $129.92 \pm 1.90 \mathrm{~A}$ \\
\hline B-22 & $123.47 \pm 0.09 \mathrm{a}$ & $127.23 \pm 0.03 b$ & $130.73 \pm 0.44 \mathrm{c}$ & $137.33 \pm 3.48 \mathrm{e}$ & $129.69 \pm 1.71 \mathrm{~A}$ \\
\hline TDZ & $125.33 \pm 0.09 \mathrm{ab}$ & $131.13 \pm 0.18 \mathrm{c}$ & $134.33 \pm 0.42 \mathrm{~d}$ & $145.70 \pm 0.49 \mathrm{gh}$ & $134.13 \pm 2.24 \mathrm{~B}$ \\
\hline $\mathrm{C}$ & $124.00 \pm 0.95 \mathrm{a}$ & $127.10 \pm 1.75 b$ & $129.07 \pm 2.12 b c$ & $134.47 \pm 5.42 \mathrm{~d}$ & $128.66 \pm 1.74 \mathrm{~A}$ \\
\hline Mean & $123.95 \pm 0.17 \mathrm{~A}$ & $129.43 \pm 0.61 \mathrm{~B}$ & $134.60 \pm 1.08 \mathrm{C}$ & $141.22 \pm 1.52 \mathrm{D}$ & \\
\hline
\end{tabular}

Means sharing similar letter in a row or in a column are statistically non-significant $(\mathrm{P}>0.05)$. Lowercase letters represent comparison among compounds and growth time while capital letters indicate overall mean according to DMRT. 
showed some growth at $10 \mu \mathrm{M}$ concentration. This compound showed better growth at $1 \mu \mathrm{M}$ concentation. The compound B-11 and B-14 had the highest percentage of developed plantlets from shoot and number of leaves per plantlet after 14 and 21 days, as shown in Figs 3b)
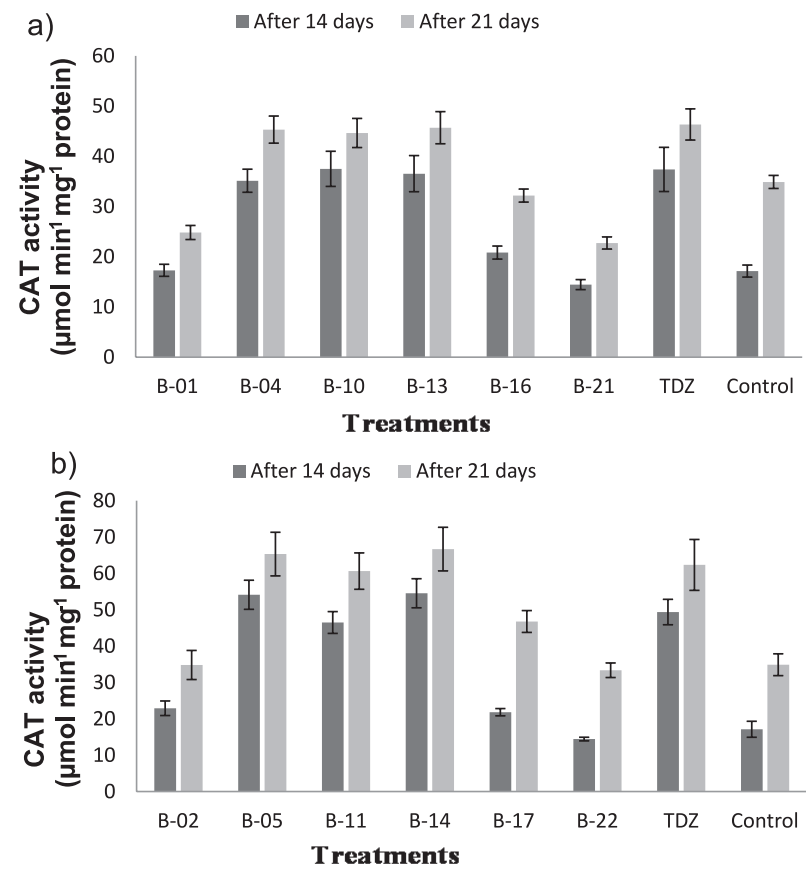

Fig. 5. Effect of synthesized plant growth promoters on catalase activity of Bougainvillea explants in response to the applied Schiff bases a) and ethyl esters b).

a)
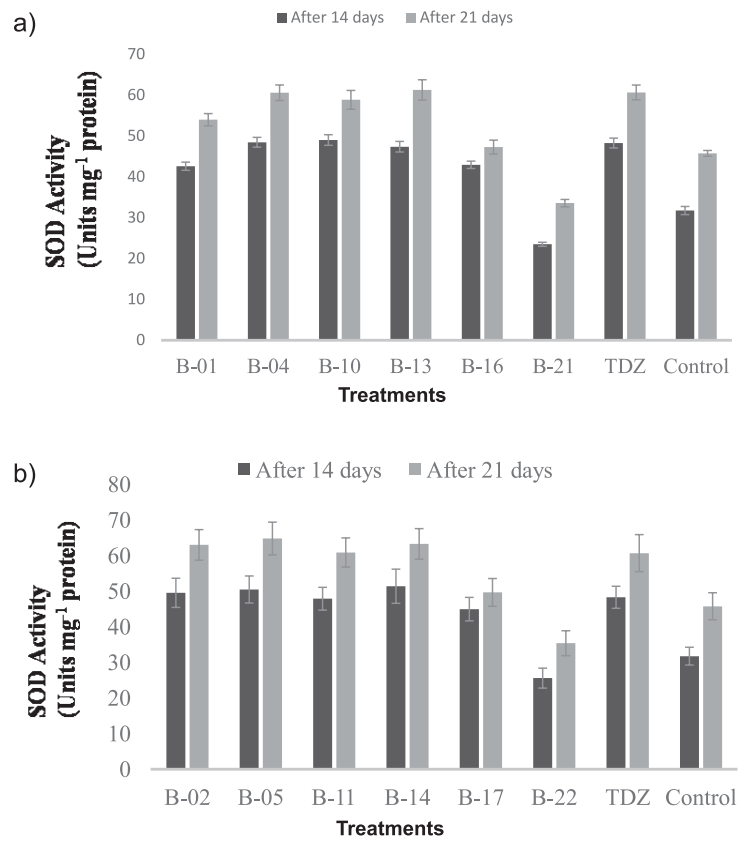

Fig. 6. Effect of synthesized plant growth promoters on superoxide dismutase activity of Bougainvillea explants in response to the applied Schiff bases a) and ethyl esters b). and $4 \mathrm{~b}$ ). These results are far better than their respective Schiff bases (Figs 3a and 4a) and the commercial standard TDZ.

Precursors of the compound B-14 are naphthyl acetic acid and benzaldehyde (prepared from reduction of benzoic acid), which have long been extensively used in agricultural practices. This compound has the smallest structure and the lowest molecular mass compared to other compounds of this series. Therefore, it is easy for the compound to mimic and deceive the receptor and trigger a growth response [36]. Similarly, B-11 also produced better response because of its small size and low molecular mass and more structural resemblance with B-14. Schiff bases showed less growth potential than their corresponding ethyl esters, and the ethyl acetate moiety (esters) gave comparatively better results. The Schiff bases B-01 and B-04 did not produce significant growth activity, while their corresponding ethyl esters B-02 and B-05 were found to be effective in shoot initiation and leaf emergence. The main cause of this difference in behavior is a single acetate moiety in Schiff bases and double acetate moiety in ethyl esters that promoted more growth in explants. Before this, new aromatic cytokinin derivatives have been prepared by substitution in the benzene ring and also in the purine moiety at the $\mathrm{C} 2, \mathrm{C} 8$, and $\mathrm{N} 9$ positions, and have shown promising properties for application in plant tissue culture and biotechnology [2]. The current compounds are synthesized from auxin moiety, but they resemble cytokinins in their behavior in triggering growth and development in plants.

Scientists are continuously in search of new biotechnologies. Sun et al. [17] have prepared derivatives from 2,4-dichlorophenoxy moieties for successful control of both monocot and dicot weeds due to their herbicidal activity. Synthesis of new compounds on plant regulator moieties is going on either to enhance and trigger more growth in commercially important plants, or to control noxious plants, weeds, and potentially harmful organisms due to their herbicidal, antibacterial, or antifungal activities.

\section{Antioxidant Enzyme Activities in Response to the Application of Synthesized Compounds}

Bougainvillea explants treated with synthesized ester-based plant growth regulators B-02, B-05, B-11, and B-14 at $10^{-6} \mathrm{M}$ exhibited considerably higher catalase activity than control, and comparable catalase activity to TDZ. The corresponding Schiff bases also exhibited better catalase activity than control, except for B-21, but lower than TDZ. Catalase activity was found to increase in 14- and 21-day-old explants treated with synthesized plant growth promoters that probably decreased the level of $\mathrm{H}_{2} \mathrm{O}_{2}$ production in the cell (Figs 5a-b). Increased catalase production was noted with the passage of time. These results are in accordance with Gupta et al. [37]. Catalase activity was comparatively high in 21-day-old 
rather than 14-day-old tissue-cultured raised plantlets. Anushi et al. [21] also found an increase in CAT level after 4 weeks as compared to 2 -week-old in vitro-regenerated shoots.

The increased level of superoxide dismutase found in explants treated with B-02, B-05, B-11, and B-14 at $1 \mu \mathrm{M}$ suggest that they help to control $\mathrm{O}_{2}^{-}$production and in fact act as the primary defense line by converting $\mathrm{O}_{2}^{-}$to $\mathrm{H}_{2} \mathrm{O}_{2}$ (Figs 6a-b) [38]. Schiff bases also produced better activity than control, but less than TDZ. Vivancos et al. [39] have also found a positive relationship between SOD and plant growth promoter application. Similarly, Agniseka at al. [23] found increased CAT and SOD production in in vitroraised shoots of Pelargonium hortorum when treated with different concentrations of TDZ. They also found a positive correlation between days of sub culturing and antioxidant enzyme production, but the increase was not linear. Anushi et al. [21] have also found increased SOD activity when plantlets of Cardiospermum helicacabum L. were treated with plant growth regulators, and their results also support our findings. Similarly, Zaheer et al. [40] have shown increased SOD levels in wheat seeds when they were soaked in different combinations of plant growth regulators.

More research is required to explore more useful derivatives and compounds synthesized from existing or new PGR-based compounds for commercial use.

\section{Conclusions}

Among the compounds synthesized with green chemistry protocols from naphthyl acetic acid moiety, the resultant compounds were characterized to be Schiff bases and their corresponding ethyl esters through IR and ${ }^{1} \mathrm{HNMR}$. The compounds B-10 and B-13 having Schiff base moiety, and B-11 and B-14 having ethyl acetate moiety, produced better growth response at $1 \mu \mathrm{M}$ concentration in tissue culture-raised explants of Bougainvillea glabra on MS basal medium compared to the commercial standard TDZ. Bougainvillea glabra explants treated with synthesized compounds also exhibited higher catalase and superoxide dismutase activity than control, and comparable activity with commercial standard TDZ. Thus, the newly synthesized compounds can prove to be alternate plant growth promoters in micropropagation of plants through the tissue culture technique.

\section{Acknowledgements}

This research was sponsored by Higher Education Commission, Pakistan [HEC ID: 112-30937-2PS1-281] and Access to Scientific Instrumentation Program of HEC, Pakistan [2(3)/HEJ/ASIP/R\&D/HEC/2016/683] for NMR analysis.

\section{References}

1. MA Q.H. Genetic engineering of cytokinins and their application to agriculture. Crit. Rev. Biotechnol. 28 (3), 213, 2008.

2. PLÍHALOVÁ L., VYLÍČILOVÁ H., DOLEŽAL K., ZAHAJSKÁ L., ZATLOUKAL M., STRNAD M. Synthesis of aromatic cytokinins for plant biotechnology. New Biotechnol. 25 (33), 614, 2015.

3. NIAZ K., BAHADAR H., MAQBOOL F., ABDOLLAHI M. A review of environmental and occupational exposure to xylene and its health concerns. EXCLI journal. 14, 1167, 2015.

4. MÉDEBIELLE M., FUJII S., KATO K. An electrochemical approach for the synthesis of perfluoroalkylated purine and indole analogues of plant growth regulators. Tetrahedron. 56 (17), 2655, 2000.

5. DOLEŽAL K., POPA I., KRYŠTOF V., SPÍCHAL L., FOJTÍKOVÁ M., HOLUB J., LENOBEL R., SCHMÜLLING T., STRNAD M. Preparation and biological activity of 6-benzylaminopurine derivatives in plants and human cancer cells. Bioorg. Med. Chem. 14 (3), 875, 2006.

6. MIK V., SZÜČOVÁ L., ŠMEHILOVÁ M., ZATLOUKAL M., DOLEŽAL K., NISLER J., GRÚZ J., GALUSZKA P., STRNAD M., SPÍCHAL L. N9-substituted derivatives of kinetin: effective anti-senescence agents. Phytochemistry. 72 (8), 821, 2011.

7. LEGRAVEREND M. Recent advances in the synthesis of purine derivatives and their precursors. Tetrahedron. 64 (37), 8585, 2008.

8. PODLEŠÁKOVÁ K., ZALABÁK D., ČUDEJKOVÁ M., PLÍHAL O., SZÜČOVÁ L., DOLEŽAL K., SPÍCHAL L., STRNAD M., GALUSZKA P. Novel cytokinin derivatives do not show negative effects on root growth and proliferation in submicromolar range. PloS one. 7 (6), e39293, 2012.

9. PLÍHAL O., SZÜČOVÁ L., GALUSZKA P. N9-substituted aromatic cytokinins with negligible side effects on root development are an emerging tool for in vitro culturing. Plant. Signal. Behav. 8 (6), e24392, 2013.

10. BARRAGÁN-MARTÍNEZ C., SPECK-HERNÁNDEZ C. A., MONTOYA-ORTIZ G., MANTILLA R.D., ANAYA J.-M., ROJAS-VILLARRAGA A. Organic solvents as risk factor for autoimmune diseases: a systematic review and meta-analysis. PLoS One. 7 (12), e51506, 2012.

11. EISLER R. Polycyclic aromatic hydrocarbon hazards to fish, wildlife, and invertebrates: a synoptic review. US fish and wildlife service biological report. 85 (1.11), 81, 1987.

12. NAIK G.N., BAKALE R.P., PATHAN A.H., LIGADE S.G., DESAI S.A., GUDASI K. B. 2, 4-Dichlorophenoxyacetic acid derived Schiff base and Its lanthanide (III) complexes: synthesis, characterization, spectroscopic studies, and plant growth activity. J. Chem. 1, 2012.

13. LIDSTRÖM P., TIERNEY J., WATHEY B., WESTMAN J. Microwave assisted organic synthesis - a review. Tetrahedron. 57 (45), 9225, 2001.

14. SUPPALAKPANYA K., RATANAWILAI S., NIKHOM R., TONGURAI C. Production of ethyl ester from crude palm oil by two-step reaction using continuous microwave system. Songklanakarin J. Sci. Technol. 33 (1), 79, 2011.

15. NAQVI A., SHAHNAWAAZ M., RAO A.V., SETH D.S., SHARMA N.K. Synthesis of schiff bases via environmentally benign and energy-efficient greener methodologies. J. Chem. 6 (S1), 75, 2009. 
16. VERMA R., KUMAR L., KURBA V.B. Green chemistry principles in organic compound synthesis and analysis. Int. J. Pharmacol. Res. 4 (1), 01, 2014.

17. SUN G.-X., SUN Z.-H., YANG M.-Y., LIU X.-H., MA Y., WEI Y.-Y. Design, synthesis, biological activities and 3D-QSAR of new N, N'-diacylhydrazines containing 2, 4-dichlorophenoxy moieties. Molecules. 18 (12), 14876, 2013.

18. SHAH S.T., ZAMIR R., MUHAMMAD T., ALI H. Mass propagation of Bougainvillea spectabilis through shoot tip culture. Pak. J. Bot. 38 (4), 953, 2006.

19. SAJID Z.A., AFTAB F. Effect of thidiazuron (TDZ) on in vitro micropropagation of Solanum tuberosum 1. cvs. Desiree and Cardinal. Pak. J. Bot. 41 (4), 1811, 2009.

20. DUHOKY M.M., AL-MIZORY L.S. In vitro micropropagation of selected Bougainvillea sp. through callus induction. J. Agric. Vet. Sci. 6, 1, 2014.

21. JAHAN A.A., ANIS M., AREF I.M. Relative examination of antioxidative enzymatic activities in plantlets of Cardiospermum halicacabum L. differentiated from hypocotyls in in vivo and ex vitro environment. Biotechnol. Rep. 4, 66, 2014

22. BADEK B., ROMANOWSKA-DUDA Z., GRZESIK M., KURAS A. Physiological Markers for Assessing Germinability of Lycopersicon esculentum Seeds Primed by Environment-Friendly Methods. Pol. J. Environ. Stud. 25 (5), 1831, 2016.

23. WOJTANIA A., SKRZYPEK E. Effects of cytokinins on antioxidant enzymes in in vitro grown shoots of Pelargonium hortorum LH Bayley. Acta Agrobotanica. 67 (4), 2014.

24. ALATAR A.A. Thidiazuron induced efficient in vitro multiplication and ex vitro conservation of Rauvolfia serpentina - a potent antihypertensive drug producing plant. Biotechnol. Biotechnol. Equip. 29 (3), 489, 2015.

25. BAIRU M.W., STIRK W.A., DOLEZAL K., VAN STADEN J. Optimizing the micropropagation protocol for the endangered Aloe polyphylla: can meta-topolin and its derivatives serve as replacement for benzyladenine and zeatin? Plant Cell Tiss. Org. 90 (1), 15, 2007.

26. ANANTHALAKSHMI S., KAVITHA R., KIRUTHIKA A., KALAIVANI S. Synthesis, Characterization and Antimicrobial Studies of Tosyl Esters of Carboxylic Acid. Int. J. Sci. Res. Pub. 4 (5), 1, 2014.

27. PATEL D.D., PATEL K.C. Synthesis and Antimicrobial Activity of New Schiff Base Compounds Containing Methylene Derivatives. Int. J. Sci. Res. 3 (12), 2594, 2014.

28. QINGCUI Y., XIAOHONG S., YUANFA L., BANG C., SHENGQIANG S. Synthesis and Antifungal Activity of Schiff Bases of 5-Ethoxycarbonylmethylsulfanyl-1, 2, 4-triazole. Chin. J. App. Chem. 31 (07), 788, 2014.
29. DACOSTA M., HUANG B. Changes in antioxidant enzyme activities and lipid peroxidation for bentgrass species in response to drought stress. J. Am. Soc. Hortic. Sci. 132 (3), 319, 2007.

30. ZHANG J., KIRKHAM M. Antioxidant responses to drought in sunflower and sorghum seedlings. New Phytologist. 132 (3), 361, 1996.

31. GIANNOPOLITIS C.N., RIES S.K. Superoxide dismutases I. Occurrence in higher plants. Plant physiology. 59 (2), 309 , 1977.

32. REDDY S.S., RAVI SANKAR A., NAGA RAJU C., KOTESWARA RAO V. Synthesis and antimicrobial activity of new $\alpha$-aminophosphonic acid esters. S. Afr. J. Chem. 61, 97, 2008.

33. POLO E., TRILLERAS J., RAMOS J., GALDÁMEZ A., QUIROGA J., GUTIERREZ M. Efficient MW-Assisted Synthesis, Spectroscopic Characterization, X-ray and Antioxidant Properties of Indazole Derivatives. Molecules. 21 (7), 903, 2016.

34. BHUSNURE O.G., VIBHUTE Y.B., GIRAM P.S., VIBHUTE A.Y. Innovative Green synthesis of Schiff bases and their Antimicrobial Activity. J. Pharm. Res. 9 (12), 670, 2015.

35. ROKADE Y., DONGARE N. Synthesis and antimicrobial activity of some azetidinone derivatives with the $\beta$-naphthol. Rasayan J. Chem. 3 (4), 641, 2010.

36. RIGAL A., MA Q., ROBERT S. Unraveling plant hormone signaling through the use of small molecules. Front. Plant Sci. 5, 373, 2014.

37. GUPTA S.D., DATTA S. Antioxidant enzyme activities during in vitro morphogenesis of gladiolus and the effect of application of antioxidants on plant regeneration. Biologia Plantarum. 47 (2), 179, 2003.

38. HUSSAIN N., CHAUDHARY M.N., ANJUM A.A., ABBAS N., KHAN M.N., NADEEM S.M. Investigating the Ameliorative Potential of the Aloe barbadensis Aqueous Fraction on Oxidative Stress Markers and Biochemical Parameters in Cadmium-Intoxicated Rabbits. Pol. J. Environ. Stud. 25 (6), 2423, 2016.

39. DÍAZ-VIVANCOS P., MAJOURHAT K., FERNÁNDEZ J.A., HERNÁNDEZ J.A., PIQUERAS A. Study of the antioxidant enzymatic system during shoot development from cultured intercalar meristems of saffron. Plant Growth Regul. 65 (1), 119, 2011.

40. AHMED Z., SHEIKH M.A., HAMEED A., UD DIN S. Investigation of Antioxidant Enzymes and Biochemical Changes in the Wheat Seeds (Freed) Induced by Different Pre-Sowing Treatments. World. Appl. Sci. J. 18 (1), 31, 2012. 